\title{
Michele Minardi. "Achaemenid Echoes in the Wall Paintings of Akchakhan-Kala, Chorasmia, and their Broader Significance for Central Asia"
}

\section{Maria Gabriella Micale}

\section{(2) OpenEdition Journals}

Electronic version

URL: https://journals.openedition.org/abstractairanica/53140

DOI: 10.4000/abstractairanica.53140

ISSN: 1961-960X

Publisher:

CNRS (UMR 7528 Mondes iraniens et indiens), Éditions de l'IFRI

\section{Electronic reference}

Maria Gabriella Micale, "Michele Minardi. "Achaemenid Echoes in the Wall Paintings of AkchakhanKala, Chorasmia, and their Broader Significance for Central Asia"', Abstracta Iranica [Online], Volume 42-43 | 2021, document 7, Online since 30 December 2021, connection on 17 December 2022. URL: http://journals.openedition.org/abstractairanica/53140 ; DOl: https://doi.org/10.4000/

abstractairanica. 53140

This text was automatically generated on 17 December 2022.

All rights reserved 


\title{
Michele Minardi. "Achaemenid Echoes in the Wall Paintings of Akchakhan-Kala, Chorasmia, and their Broader Significance for Central Asia"
}

\author{
Maria Gabriella Micale
}

\section{REFERENCES}

Michele Minardi. “Achaemenid Echoes in the Wall Paintings of Akchakhan-Kala, Chorasmia, and their Broader Significance for Central Asia", Journal of Asian Civilizations 43 (2020), p. 1-41.

1 The Author, with his very long and articulated argumentation, presents the wall paintings of the Central Building of the royal Chorasmian Ceremonial Complex at Akchakhan-Kala, attributed to Phase/Stage 3 of the settlement (1st cent. BC to 1st cent. $\mathrm{AD})$, as an opportunity to attempt a reconstruction of the artistic and historical background of some iconographic motives of those paintings. The A. had already published these paintings which represent three colossal human-like figures (all described as possible deities) and often makes references to his previous or forthcoming publications - not only for the paintings themselves, but also for the architectural and topographic contexts as well as for the historical setting of Akchakhan-Kala and its region.

2 The core of the A.'s argument is the description of some decorative elements and iconographic details in the representation of the three deities- elements and details that he defines as having Achaemenid origins. According to the A., the perspective representation of the three figures as well as their garments, for example, find earlier 
parallels in Achaemenid art. Also the so-called corona muralis is, in the A.'s opinion, an iconographic element of Achaemenid descent. However, what seems to be recognized as an unicum in the entire region's art is a series of lions' heads conceived by the artist as a continuous decorative pattern along the external edge of the central figure's garment. These heads have, for example, their earliest parallels (and possibly most striking for iconography and meaning) in the Achaemenid golden bracteates of the Oriental Institute Museum in Chicago. The A. also mentions other Museum collections for similar pieces, though without providing references for them. The publications of Kantor and Moorey that he refers to, in reality, do not mention any of these other collections, so these data remain unfortunately inaccessible.

It is not clear why the A. seems to exclude a nomadic component, especially in the representation of the lions' heads - which seem clearly to be representations of metal bracteates on textiles, a very common feature of nomadic art. Helen Kantor herself, in the publication that the A. quotes, sees in the detached lions' head the very spirit of nomadic art that participated in the formation of Achaemenid art, according to a reciprocal influence that lasted well beyond the collapse of the Persian empire. The nomadic nature of Achaemenid traditions may point, I would say, to the Medes, as well as to what Helen Kantor sees as the tradition of Median gold-working. Moreover, the co-existence of Achaemenid and Assyrian (more than generally defined "Near Eastern" [p. 15]) iconographic features that the A. rightly recognizes in the tree-bark or mountain pattern decorating the cape of the third deity of the depicted group may support the hypothesis of a Median "connection".

4 The A. explains the presence of these Achaemenid iconographic elements, especially the lions' head, with the persistence of Achaemenid elements in the region in a tradition that, however, is admittedly difficult to demonstrate. The use of these elements and their combination have no parallels either in the region or in the courtly art of Central Asia, so the reason why these Achaemenid iconographic elements survive, as well as the path that brought them to Akchakhan-Kala, remain in the realm of the hypothesis. However, especially because of the uniqueness of the datum, and despite the lack of a supportive archaeological and textual evidence, the A. doesn't give up on the hypothesis that the representation of the three deities reveals the existence of a local tradition, possibly an uninterrupted tradition, that originated in Chorasmia directly (or indirectly) under the Achaemenid influence centuries before-though the hypothesis of a later input mediated through a former satrapal centre via Hellenistic craftsmen seems to be equally taken into consideration.

5 From an art historical point of view, the A.'s terminology shows an evident ambiguity in the use of some words. This ambiguity leads to a diminished clarity of the theoretical underpinnings of the present study. Archetypes and models, reflections and echos, persistence, continuity and transmission, adoption and tradition, are not neutral words. The transmission of images through Antiquity, the relationship between archetypes and meaning, i.e. transmission of images and possible transmission of their meaning lay at the core of the historical research on ancient iconography. To cite one example, in R. Bianchi Bandinelli's studies that the A. seems to elect as methodological model (pity for a bad typo in his quotation). The A.'s goal is ambitious and anything but simple (as well as far from been reached, by his own admission). However, though sometimes confusing, his arguments give us already some glimpses of future research paths. His refusal of the idea that Achaemenid motives could have been chosen as an 
alternative to Hellenistic motives for ideological reasons is already a sort of denial of any conscious choice for Achaemenid symbolic images. In fact, he speaks of a "new interpretation of old iconographies" (p. 23), "transformation in style and content", however "under active royal and religious patronage mainly for political reasons" ( $p$. 22). It would be fundamental in the future to understand the ideological background for the choice of specific motives and the alleged new meanings attached to them. Whether the original Achaemenid image had already lost the original significance along the path of its transmission/migration before being selected at Akchakhan-Kala or not may be a topic for a future discussion - one can hope that the A. takes up this question in future research.

\section{AUTHORS}

\section{MARIA GABRIELLA MICALE}

Freie Universität Berlin 